Borys Savchuk, Doctor of History, Professor, Professor of Department of Pedagogy named after Bogdan StuparikVasyl Stefanyk Precarpathian National University, Ivano-Frankivsk, Ukraine ORCID: 0000-0003-2256-0845 ResearcherID: 2903385

Yaroslav Vovchok, $\mathrm{PhD}$ (Candidate of Pedagogical Sciences), associate professor, Department of Foreign Languages Vasyl Stefanyk Precarpathian National University, Ivano-Frankivsk, Ukraine ORCID: 0000-0001-8542-3026

ResearcherID: M-5030-2017

Halyna Bilavych, Doctor of Pedagogical Sciences, Professor, Professor of Department of Pedagogy of Primary Education of Vasyl Stefanyk PrecarpathianNational University, Ivano-Frankivsk, Ukraine ORCID: 0000-0002-1555-0932 ResearcherID: 2151427

\title{
STUDENTS' TRAINING TOWARD NOSTALGIC TOURISM ORGANIZATION (THE STUDY PROJECT IMPLEMENTATION EXPERIENCE)
}

Nostalgic tourism is a promising trend of tourism industry, which has significant economic, cultural, international importance for the development of Ukraine. However, its potential is not completely used particularly because of poor training of tourism managers. Thus, it creates the need to design special educational programs for managers ready to work with this category of tourists. While conducting the research, we relied on experimental methods (surveys, modeling, contextual approach), as well as the methods of educational process (design technology, roleplaying, trainings, summaries of multilingual text excursions etc.).

The article represents the experience of study project implementation «IvanoFrankivsk: Polish nostalgia» with graduate students of tourism department of Vasyl Stefanyk Precarpathian National University (Ivano-Frankivsk, Ukraine). It consisted 
of two parts: predictive (84 students and 25 managers of travel companies were interviewed to identify nostalgic understanding of tourism and willingness to work on its development) and educational- organizational.In the development of tourist routes, the conceptual idea was realized: to show Ivano-Frankivsk as a unique example of an ethnic cross-border with a tolerant symbiosis of different cultures, as Ukrainians, Poles, Jews, Armenians, Germans, representatives of other nationalities have lived here for centuries. The technological content of programs along with the nostalgic trips for tourists from Poland were described, which consisted of theoreticalscientific, educational-technological and practical -approbational blocks showing cognitive, educational, ideological importance of nostalgic tourism both for the training of future tourism managers and for various categories of foreign and domestic tourists.According to the results of the research experiment, a number of principals of theoretical, practical and organizational character, which may become the subject of scientific discourse, have been formulated.

Key words: training of tourism managers, a study project, nostalgic tourism, sightseeing training, methodology of study projects.

Introduction. Tourism is a promising area of economic and cultural development of Ukraine. Although today it forms less than 1\% of its GDP, according to the search engine TripAdvisor, the interest in our country is growing, particularly among the citizens of the US, UK, Germany, Poland and other countries. Therefore, analysts say that the activity in the tourism market of Ukraine might quickly rise by $80 \%$, and mainly cultural tourism is considered very promising (Vnutrenniy mir).

Ukraine's tourism potential is inhibited by objective (a difficult military, political, social and economic situation) and subjective factors, including the inability of tour operators to create quality product. It creates the need to improve the training of future tourism managers in higher educational institutions (HEIs) based on innovative technologies.

One of the most promising types of tourism is nostalgic due to such factors. First, it has a large base of potential customers, because based on four waves of immigration in the late XIX - early XXI century Ukrainian Diaspora was formed in Europe and America, which currently has about 13-15 million people - natives of Ukraine and their descendants. We can count on domestic tourists as well, who are interested in national culture as potential participants of this type of tourism. Second, Ukraine has powerful recreational resources (authentic monuments of culture, national traditions, etc.), which require skilled backing in the tourism market.

The research of nostalgic tourism phenomenon was intensified in the late XX - early XXI century. Ukrainian scientists A. Vilczynski, L. Kyrylyuk productively developed terminology of the given type of tourism. V. Kyfyak, M. Kliap, S. Malov paid their attention to its types and classification. Scientific and practical aspects of its development in the country and its particular regions were subject of study by 
P. Putsenteylo, F. Shandor, L. Shevnina etc. Foreign scientists G. Berrisford, H. Hodgson are famous for their works, which reflect the diversity of approaches to determining the objectives, content of nostalgic trips. A. Leon, G. Malinovski, G. Dann (Dann G., 1994), D. Russell (Russell D., 2008), (Jarratt D., \& Gammon S., 2016) studied motives of such travels. A. Fernham, J. Veverka (Veverka J.), P. Robinson (Robinson P., 2015), C. Routledge (Routledge C., 2016), andsome others were interested in their structure, number of participants and other organizational problems. Analysis of the studies of the given problem showed that the problem of special preparation of students in relation to nostalgic tourism hasn't actually been developed.

Specified and other factors led to the organization of the study- research project «Ivano-Frankivsk: Polish nostalgia» with graduate students (18 people) of Tourism Department of Vasyl Stefanyk Precarpathian National University (PNU) while conducting the course of «Nostalgic tourism of Precarpathian region». Thus, we were guided by such motives. First, the territory of modern Ivano-Frankivsk region was part of Poland during several centuries. As a result many monuments of Polish culture have been preserved here. Ivano-Frankivsk maintains close economic and cultural relations with Poland, which is home to tens of thousands of Poles (born in Western Ukraine) and Ukrainians, who went there in the late XX - early XXI century for various reasons. Customer base of nostalgic tourism is also made up of their descendants, members of business tourism and other categories of tourists interested in national culture. Second, while studying at the University, the graduate students gained basic knowledge of the Polish language and specialized subjects, which created the necessary basis for the implementation of the given project.

The paper aims to present the experience of implementation of the study project «Ivano-Frankivsk: Polish nostalgia» that can be used in the organization of nostalgic tourism in Ukrainian and foreign universities, and to determine the prospects of practical development and theoretical understanding of this area of tourism.

The task of the research is to assume that the efficiency of future tourism managers' training in Ukrainian Universities will be promoted by the use of innovative methods while creating multilingual tourist projects, which stimulate their job research, develop initiative, creativity, self-discipline, communication, raise the overall level of professional training.

Research methods. The methodology of research-experimental work is divided into two main components (stages): diagnostic and educational- technological. Diagnostic experiment was conducted in January 2016 among 84 students of fifth-year of study in Tourism Department of Vasyl Stefanyk Precarpathian National University and 25 managers of travel companies in Ivano-Frankivsk. Thus, two questionnaires were created, which were to reveal the understanding of nostalgic tourism and willingness and understanding of the prospects for its development. Half the managers had no special education, but considered themselves to be competent to organize tourism activities. 
The questionnaire included one «open» and six «closed» questions. Responses to «closed» questions were assessed on a 5-point scale (5 - «high», 4 - «enough», 3 «average», 2 - «low», 1 - «inadequate characteristics»), and the results were assessed and compared by the method of relative frequencies described by V. Sidorenko and N. Tverezovska (Tverezovska N. T., 2013, 370-377). The received data suggest the objective results of the initial experiment.

Educational- technological component provided the organization of the project based on modeling techniques, contextual approach, linguistic training projects and other methods and techniques. Their principles were developed by national and foreign scientists.

Modeling technology (Miheev V. I., 2006) is aimed at creating a model (an analogue) to serve as an intermediary between the subject (student / teacher) and object of the study. It recreates real natural environment to create tourism product and provides the relationship between the objectives, content, organization and definition of its ultimate quality. We used the following types of models: predictive (specification of objectives, distribution of resources to achieve them); conceptual (action program based on informative analysis); instrumental (methods and means of implementation).

Contextual approach (Verbytskyi A. A., 2004)provided consistent transformation of content of general and professional disciplines («Culture», «Foreign Languages», «Excursions» and others) into the subject of professional activity. It meant the approach of professional training of future managers to the realities of the tourist market through self-improvement.

Methodology of the study project activity was used in two ways. The first one relates to its general theoretical and practical principles (Kolesnikova I. A. 2008), which in accordance with the objectives of our experiment involves the formation of skills to independently and creatively plan the work and make decisions; accumulate, organize, analyze, correlate information; support one's position; combine individual and team forms of work; create and present the «final product»; evaluate oneself and others. The following types of study projects were tested: search, information, research, practice-oriented, role-playing.

The second aspect relates to the methods of students' training to create multilingual tourism products, mainly thematic tours (ChufarlichevaA. Y., 2010; Ivanova I. M., 2016).It includes: a) building knowledge and skills to interprete texts in the form of logical-semantic analysis of sources in accordance with the objectives, content, structure and other dimensions of tourism products; b) taking into account stylistic and genre features and characteristics (audience, purpose, organization, style and presentation of texts).

Research Results and Their Discussion. The main material of the study reflects the state of willingness and preparation of future managers and tourism 
employees to work on the development of nostalgic tourism and the content of the study project to prepare students to carry it out.

Analysis of responses to the questionnaire what nostalgic tourism is showed a vague idea about this phenomenon. Mainly, $45 \%$ of the students and $64 \%$ of the managers actually identified it with ethnographic tourism; $48 \%$ and $24 \%$ respectively linked it to traveling of foreigners, mostlyformer immigrants to their homeland to visit relatives, the graves of ancestors; and $7 \%$ and $12 \%$ could not give a clear answer.

The respondents showed a low level of self-evaluationto be prepared to organize nostalgic tourism: students $-27 \%$, managers $-32 \%$. The reasons for this situation is lack of cognitive (understanding the essence, the importance of this type of tourism) and motivational components' development since only $21 \%$ of the students and $17 \%$ of the managers could identify the perspectives for its development in IvanoFrankivsk region.At the same time they preferred other different proposed types of tourism: historical-cultural (67\%), folklore-ethnographic and eventful (51\% and 44\%), health (42\%), business (38\%), gastronomic (27\%).

Such reflections are due to the respondents' evaluation of tourism resource base in Ivano-Frankivsk region (architecture, landscapes, spa resorts, traditions, museums), which are not linked with nostalgic tourism. They claimed that its main participantswere usually senior citizens who left their native land, and in some cases their descendants.

$54 \%$ of the students and $74 \%$ of the managers showed a high level of communicative component to be prepared to organize nostalgic tourism basically due to their orientation on Ukrainian-speaking participants. However, they admitted to havinga low level of training to conduct tours in English and Polish languages(students $17 \%$; 24\%; managers $-10 \%$ ), although they understood the need to possess such professional knowledge and skills (34\% and $42 \%$ respectively). Significant differences in the cognitive activity of the students (14\%) and managers (46\%) reflect the need to expand knowledge about the prospects of nostalgic tourism development and to increaselanguage professional competence to conduct tours with its participants.

The results of prognostic experiment allow the following interim Conclusion: a) both groups of respondents expressed a low level of trainingto develop nostalgic tourism, which was due to misinterpretation of its nature, resource base, potential customers and prospects of the development in comparison with other types of tourism; b) despite the mutual low level of training to conduct excursions in foreign languages, the managers considering their experience and understanding the prospects of tourism developmentrevealed deeper understanding and willingness for further professional development.

These results were taken into account while organizing the second phase of research- experimental work realized in the form of the training project «IvanoFrankivsk: Polish nostalgia». It consisted of three parts: a) scientific-theoretical (four classes); b) scientific-technological (six classes); c) practical approbation (three 
classes, excursions). Each of them had their tasks, stages, methods of implementation. Additionally, consultations and various kinds of individual work were performed.

Scientific-theoretical block was designed to form students' insight intothe nature, potential and other characteristics of nostalgic tourism. The following methods were used: search-heuristic, content-analysis, «brainstorming», «case method», discussions.

The students themselves searched for the answers to factual and problematic questions such as: when did the concept of »nostalgic tourism» derive, what are some scientific approaches to understanding the essence of nostalgic tourism, what are some common and different views on nostalgic tourism among foreign and Ukrainian scientists, what is the difference / similarity in terms of «ethnic tourism», «nostalgic tourism», «cultural tourism», who are potential participants of nostalgic tourism, what factors stimulate and inhibit the development of nostalgictourism, what motives encourage people to participate in these tours and so on. To prepare answers to them the graduates had to work 4-5 publications from the list of reference literature and to find 3-4 articles on this topic themselves. Four classes were granted for the discussion and development of the theoretical part of the study project. On the first one there was a discussion on understanding the essence of nostalgic tourism, which was identified with the ethnic or inbound tourism; with travels to places that preserved authentic models of ethnic culture and so on. The students also discussed questions if nostalgic tourism can be included ininternational or domestic tourist flows; its structure of participants and others. The aim of the second class was to develop a consolidated position on the understanding of the basic aspects of nostalgic tourism. The results of mini-research were made. Thus, based on etymological analysis the student Iryna Pavliv showed that ethnic (from Greek "E $0 v \mathrm{vo}$ - tribe, people) and nostalgic (from Greeknostos-returning home, algos - pain) types of tourism have different objectives because the main motives of nostalgic travels are longing for home, the desire to visit the place where the person was born, their parents, to know the ethnic roots.

During the next two classes the theoretical part of the study project was being developed. The edited materials of the above presentations formed its basis. Nostalgic tourism is defined as a separate type of tourist trips that had ideologically-cognitive tasks, and were motivated by sensitive-emotional experiences and willingness to form their own ethnic identity, becoming part ofthe authentic culture of the people returning to places associated with important events of life. The factors, categories of participants, resource provision of nostalgic tourism were defined as well as the possibilities to combine it with other types of tourism and its influence on shaping the image of the country, preservation of cultural heritage, improving the infrastructure and so on.

Having observed the work of students,we can say that they completely independently and «surprisingly» for themselvesdiscovered this powerful trend of tourist activities and realized its great prospects. 
The basis of practical - technological part of the study project was to developfive Polish-speaking thematic excursions around Ivano-Frankivsk. Some minigroups of 3-4 people were created, which used different methods, forms, means of work.

While improving their knowledge and skills in Polish, organizing excursions and other professional disciplines, students worked on technologiesof designing tourist routes. In particular, the method of planning walking excursions by J. Veverka (Veverka J.) was adapted to the conditions of the development of nostalgic tourism in Ukraine, which allows to effectivelyrepresent the cultural heritage of small towns through original practically oriented technology of their conduct.

While developing tourist routes, our conceptual idea was realized: to represent Ivano-Frankivsk as a unique example of ethnic crossroads with tolerant symbiosis of different cultures, becauseUkrainians, Poles, Jews, Armenians, Germans and other nationalities lived here together for centuries. This approach contributes to intercultural dialogue with foreign tourists, as well as raising students' interest and respect for cultural values and heritage of their own nation and other peoples.

In accordance with our «matrix», tours were to: a) begin with a review of the history of the city of XVII-XVIII centuries, when its owners were Polish magnates Potocki; b) represent monuments of Polish culture along with Ukrainian, Jewish, German ones and certify their current functionality; c) use the infrastructure of the city for a comfortable stay of guests; d) offer a flexible portfolio of a tour- guide that focuses on the interests of tourists. At the same time tours were designed: a) tailormadefulfilling personal wishes of tourists; b) complex, which combined nostalgic tourismwith festival, health, gastro and other types of tourism.

As an example, the following excursions are worth noting: «Sacred places of Ivano-Frankivsk» (involves visiting 7-12 the most famous sacred buildings of the city: the Collegiate church of XVII (now the Art Museum), Jesuit church (1729, now the Cathedral of St. Resurrection of Ukrainian Greek-Catholic church), the church of the Jesuits and the House of clergy (1895), the church of St. Joseph (1927), Armenian church (1762) and others.); «Stanislav architecture of XVIII - XX centuries.» (allows to see 10-15 old buildings); «Wandering the streets of Ivano-Frankivsk» (represents the building history, administrative and civil monuments of XIX - early XX century), and others.

The sightseeing program «Polish necropolis» makes way to the Memorial park to explore the tombs of famous Polish figures: a poet, member of the Polish uprising of 1831 Mauritius Goslavskiy (opened in 1875, the monument is the oldest in the cemetery and repeatedly restored); Stanislaviv's community leader Sigmund Mrachkovskiy (a seven-meter tombstone is the highest in the cemetery); Jozefa Dzvonkovska, an interpreter, Ivan Franko's «second love»; remnants of tombstones with artistic value; a memorable sign to the Polish people who died in 1914-1919; Ukrainian military graves and cultural figures. 
The proposed sightseeing tours offer the main tourist attractions of IvanoFrankivsk: the City Hall (the first version was built in 1666); Potocki Palace with the gates (1662-1682); Mickiewicz Square, where the monument to the writer is located (1898), and the Regional Philharmonic theatre (1891); remnants of the fortress (end of the XVII century), etc. What about eateries we preferred the restaurant-antique «Spindle», the interior of which is decorated with antiques and postcards of the early twentieth century.

Individual classes played an important role to prepare excursions in the Polish language. To improve the linguistic competence of the students different principles, methods and techniques were used. Thus, the principle of visuality provided analysis and selection of the most interesting textual materials, pictures, photographs that reflect the original appearance of houses and buildings of the city; charts and maps for planning itineries and so on. Methodical guidelines by I. Ivanova and A. Chufarlicheva, which are built on the principles of projecting technology, helped to master the skills of handling specific lexical units for the compilation of excursions, which revealed clearly and vividly the content of historical and cultural events.

The third practical-approbational stage of the study project included classroom lessons and excursions for Polish tourists. The first part was based on the methodology of business games and professional trainings that allow students to simulate sightseeing activities through the presentation of educational projects; develop the skills of professional communication through acting out different communicative situations and so on. The students' discussion of their results was accompanied by debates and mutual criticism of hypotheses and proposals that promoted the formation of new knowledge, ideas and experiences of professional activity.

Students conducted tours for different categories of Polish tourists: students and scientists who were invited to Ivano-Frankivsk by PNU; participants of folk festivals, who were mostly immigrants from western Ukraine, as well as their descendants and others. Four individual tours aroud Ivano-Frankivsk region to places where they were born or their relatives live were organized.

Implementation of the study project encourages to discuss a number of questions concerning the interpretation of nostalgic tourism and improvement of future managers' training toward its organization. The first issue is related to the fact that the Ukrainian tourism science gives a narrow interpretation of this concept as a kind of tourist services designed especially for elderly people, usually former immigrants seeking to visit their motherland. Meanwhile tourism experts and managers of the Western countries give a broader definition of nostalgic tourism. In particular, G. Hodgson, the chairman of the North-East Tourism Advisory Council of England explains a progressive trend in recent years why the British prefer to travel within their own country because of the desire to experience «authentic atmosphere». This involves visiting rural pubs, familiarization with the local architecture and ecoenvironment, tasting local food, drinks and so on. Summarizing this situation, his 
colleague G. Berresford said: «This is a very rewarding experience to revive our country, because it is clear that once you do it, you want to do it all over again» (Site of Newspaper Financial Times).

The results of the survey, which involved 500 people, and which was conducted by a senior professor of psychology at University College of London A. Fernham, show a very interesting trend of nostalgic tourism development. He found out that their trips were motivated by the desire to return to the placeof their childhood $(27,7 \%)$, to where they lived and studied in early years $(21,5 \%)$, had a honeymoon $(5,8 \%)$, had an unforgettable romantic affair $(5,5 \%)$, spent their vacation $(4,4 \%)$, got married $(4,4 \%)$ (Site of Tour Operator Travel Mole).

Thus, functional features of nostalgic tourism are extremely wide and it can become a powerful trend of domestic travels and involve different types of people. This idea should be formed in future tourism managers.

The second problem brought to the discussion is the fact that Ukrainian scientists mainly focused on the formation of the English-speaking professional competence of future tourism managers (I. Ivanov, A. Chufarlicheva, L. Shevnina), so in fact no strategies of studying in other languages were researched. Implementing of our research project overcomes this situation and on the example of the prepared textual materials for excursions proves the effectiveness of parallel training in the two languages - Ukrainian and Polish. This widens their practical application because, it is quite possible that tourists from Poland, who were born in Ukraine, will be willing to listen to the tour in their native language,whereas their descendants - in the Polish. This approach is appropriate becausefuture tourism managers also form the skills of conveying specific textual information from Ukrainian into any other foreign language, taking into account its specific vocabulary (borrowings, historicisms, ethnographisms).

Conclusion. In line with the results of the research experiment we can formulate a number of thesises of scientifal-theoretical and practical-organizational nature, which may become the subject of a scientific discourse. First, in the further development of scientifical-theoretical basis of nostalgic tourism we offer to regard it as a separate type of travels, which is closely connected with other types of tourism. It has a big base of potential customers, which is not limited only by residents of certain areas and their descendants, but also comprises those seeking to know the authentic culture of their and other nations, wanting to visit places that bring back memories of important events of the past.

Second side is such a reflection of nostalgic tourismrequires specific approaches to the methods of its organization. It must take into account not only the needs of individual groups of tourists, but also offer tailor-made tours according to personal wishes of customers who, for example, want to combine a visit to a «place of nostalgia» or their relatives withbetter acquaintance of the culture and life of the region, ethnic group and so on. So, on the one hand, nostalgic tourism excursions 
should be flexible, «mobile» compared with other types of tourism, on the other hand, it is expedient to combine them with eventful, gastronomic and other types of tourism, which intensify emotional excitement and make cultural authenticity of the region distinct.

Third, the conducted experiment proves the effectiveness of applying different kinds of study projects to prepare future tourism managers, whichgauge their independence, responsibility, creativity, ability to work in groups and individually, willingness to constant research and improvement.

Fourth, the students' reports on the results of excursions and tours held for foreigners have provedthe efficiency of the borrowings: on the one hand, tourists not only cheerfully responded to words, names related to housing, food, beverages, cultural phenomenaborrowed from their language, but also asked to explain their specific substantial meaning in the Ukrainian language. On the other hand, the Polish tourists with genuine amazement learned about the spread of Ukrainian words (soup, dumplings, hopak, Kobzar, etc.) within their language lexicon.

Fifth, the problem of the formation of foreign language professional competence is usually studied by scientists-linguodidactics. Under these conditions, the content of training of specialists for professional activities in various fields (education, tourism, law, economics, etc.) is «formal informative material» to implement merely linguodidactic scientific-research tasks, so they are more or less focused on professional training in other fields. So the solution to such problems requires consolidation of efforts of different disciplines.

Sixth, we state a strong educational, cognitive, ideological impact of nostalgic tourism that forms in students love and respect for the culture of their and other nations, and their conscious need for professional self-improvement; in foreign tourists the recognition of cultural values and sense of respect for Ukraine; in tourists from different regions of Ukraine - a sense of inner unity and awareness of common national roots.

\section{REFERENCES}

1. Caton, K., \& Santos, C. A. (2007). Heritage tourism on Route 66: Deconstructing nostalgia. Journal of Travel Research.45(4). 371-386. DOI : 10.1177/0047287507299572 [in English].

2. Chufarlicheva, A. Y. (2010). Metodyka navchannia maibutnikh menedzheriv turyzmu stvorennia anhlomovnykh turystychnykh proektiv [Methods of training future tourism managers to create tourism projects in English]. Extended abstract of Candidate's thesis. Kyiv. [in Ukrainian].

3. Dann, G. (1994). Tourism and nostalgia: Looking forward to going back. Vrijetijd en Samenleving. 12 (1/2). 75-94. [in English]. 
4. Ivanova, I. M. (2016). Pryntsypy formuvannia u maibutnikh fakhivtsiv sfery turyzmu profesiino oriientovanoi anhlomovnoi kompetentnosti $\mathrm{v}$ ukladanni tekstiv ohliadovykh ekskursii [Principles of teaching future tourism specialists professionally oriented English language competency to edit sightseeing tours'scripts]. Visnyk of Chernihivskoho Natsionalnoho PedahohichnohoUniversytetu- Bulletin of Chernihiv National Padagogical University.141. 73-77. Retrieved from: visnyk.chnpu.edu.ua/?wpfb_dl=2959 [in Ukrainian].

5. Kolesnikova, I. A. (2008).Pedahohicheskoe proektirovanie [Projection in pedagogy]. Moscow: Academy. [in Russian].

6. Miheev,V. I. (2006). Modelirovanie i metody teoriy izmereniiy v pedahohike [Modeling and methods of measurement theory in pedagogy]. Moscow. [in Russian].

7. Robinson, P. (2015). I Remember it Well: Epiphanies, Nostalgia, and Urban Exploration As Mediators of Tourist Memory.Tourism Culture \& Communication. 15(2). 87-101. DOI : 10.3727/109830415X14401707765881 [in English].

8. Routledge C. (2016). Nostalgia, a psychological resource. New York/Oxon, Routledge. [in English].

9. Russell, D. (2008). Nostalgic Tourism. Journal of Travel \& Tourism Marketing. 25(2).103-116. DOI: 10.1080/10548400802402271 [in English].

10. Site of Newspaper Financial Times «Authenticity and nostalgia boost tourism». Retrieved from: https://www.ft.com/content/17ba137c-a171-11df-965600144feabdc0 [in English].

11. Site of Tour Operator Travel Mole «'Nostalgia tourism' uncovered as new trend». Retrieved from: www.travelmole.com/stories/1124918.php [in English].

12. Tverezovska, N. T. (2013).Metodolohiia pedahohichnoho doslidzhennia [Methodology of scientific research]. Kyiv. [inUkrainian].

13. Verbytskyi, A. A. (2004).Kompetentnostnyi podkhod i teoryia kontekstnoho obuchenyia [Competitive approach and theory of contextual teaching]. Proceedings of Seminar. Moscow. [in Russian].

14. Veverka, John A. Planning interpretive walking tours for communities and related historic districts. Retrieved from https://portal.uni-freiburg.de/.../veverka planning-interpretation. [in English].

15. Vnutrenniy mir. Optymystycheskaia statystyka Trip Advisor ob Ukraine [Trip Advisor's promising statistics about Ukraine]. Retrieved from: forbes.net.ua [in Russian]. 